\title{
Senate Reform and the Political Safeguards of Canadian Federalism in Québec
}

\author{
Jean-Christophe Bédard-Rubin*
}

Unlike in Canada, the doctrine of political safeguards of federalism is a tantalizing presence in American constitutional law that changing tides and moods have never completely submerged. The core idea is simple: political institutions in the United States have been designed to ensure that interests of the states are represented in the federal decision-making process. Thus, the judiciary does not need to intervene to police the federal division of powers. ${ }^{1}$

As Justice Harry Blackmun summarizes for the majority of the United States Supreme Court in Garcia v. San Antonio Transit Authority:

[T]he Framers chose to rely on a federal system in which special restraints on federal power over the States inhered principally in the workings of the National Government itself, rather than in discrete limitations on the objects of federal authority. State sovereign interests, then, are more properly protected by procedural safeguards inherent in the structure of the federal system than by judicially created limitations on federal power. ${ }^{2}$

The idea was not new, but it has had periods of latency and revival in American constitutional law. ${ }^{3}$ In the classical formulation of the doctrine, the United States Senate is perhaps the most important safeguard of American federalism. ${ }^{4}$ It is a strong upper chamber with an effective legislative veto that, unlike most other bicameral systems in the world, cannot be overruled by the other proportional chamber (i.e. the House of Representatives). ${ }^{5}$ Because every state has two senators - and thus, an equal voice in this part of the national legislative process, be it
Wyoming with 585000 inhabitants or California with 39250000 inhabitants ${ }^{6}$ - the Senate can be a stronghold of state interests and play quite an important political role.

The political fate of the Canadian Senate has not been as salient as its American counterpart. It was already seen as a moribund institution in the middle of the twentieth century and has remained as such until recently. ${ }^{7}$ For example, in 2016, a careful observer like Wade K. Wright could still note that "there is fairly widespread agreement that the Senate has proven to be largely ineffective as a political safeguard of federalism." ${ }^{8}$ However, in light of the Trudeau government's new Senate appointment policy and institutional reform, the meaning and the role of the Senate in Canada's constitutional architecture might change. The Senate reform could transmute what was a politically moribund institution into a genuine political safeguard of Canadian federalism. The path is neither straightforward nor ineluctable, but recent events seem to suggest that Québec, at least, is willing to step into that newly-opened door. The aim of this article is to chronicle this change by focusing on Québec's recent attempts to channel its political grievances through the Senate.

\section{Representation and Legitimacy or Vice-Versa}

Prime Minister Justin Trudeau's reform of the appointment process to the Senate came at the end of a long and winding road. The Conservatives and the Reform Party before them had 
repeatedly promised a "Triple-E" Senate, one that is equal, elected and effective. While in power with a majority Government, however, the efforts of Stephen Harper's Conservative Government were stopped by the 2014 Senate Reference in which the Supreme Court of Canada more or less closed the door to senatorial election without a formal constitutional amendment to that effect. Despite the Court's ruling, there seemed to be a growing consensus in Ottawa that things could not stay as they were especially after a string of scandals plagued prominent senators contemporaneously to the Senate Reference decision. ${ }^{10}$

Thus, the Liberals' revival of the Senate as a chamber of "sober second thought" can be seen either as a consolation prize or as a real attempt to reinvigorate a dying institution and retrieve its authentic meaning and mission. Regardless of one's reading of the situation, the Liberals might have succeeded in achieving a genuine reform neither by undergoing the stringent constitutional amendment process nor by transforming the Senate into another elective house of Parliament. ${ }^{11}$ First, on January 29, 2014, while in the opposition, Trudeau's Liberal party excluded senators from its caucus, thus providing the "liberal"-now-independent senators with the political independence necessary to exercise their political judgment without the oversight of the Party Whip. Second, shortly after taking power in October 2015, Prime Minister Justin Trudeau announced that he would use a new procedure to select senators, a procedure that "is designed to help ensure that the Senate is independent, reflective of Canada's diversity, and best able to tackle the broad range of challenges and opportunities facing the country." 12

The combination of the new appointment process and the severance of the political ties of senators was likely to modify the work of the Senate. By replacing political patronage with competence, the Liberals could reinvigorate the Senate and build its institutional legitimacy. The Senate has resolutely felt emboldened by the change; in the first two years of the Trudeau Government, the Senate has amended about 25 percent of the bills passed in the House of Commons. By comparison, during the ten previous Parliaments, the Senate amended, on average, seven percent of House bills - an important change to say the least. $^{13}$

It is interesting to note, in this respect, that it is precisely because the Senate is not elected that it can potentially play its role of advocating for the different regions of the country. If it were to become an elected upper house of Parliament, it is unlikely that senators would run on totally different platforms than the MPs of the House of Commons. In the United States, for example, the original design of the Senate gave an equal representation of two senators per state in order to protect the interests of the states. Senators were to be sent to the United States Congress after having been nominated by their State legislature. These senators could indeed be a decentralizing force and protect state interests because they had a clear political incentive to do so; they were appointed by state authorities themselves. However, from the middle of the $19^{\text {th }}$ century onwards, some states started to directly elect their senators. By 1910, 28 out of 46 states had changed their appointment procedures and most senators were thus directly elected. ${ }^{14}$ With the adoption of the seventeenth Amendment (1913) that provides for the direct election of all senators by the population of every state, the structural mechanisms do not play their initial role anymore. Citizens are generally more interested in what governments do than which government does it. Thus, senators do not have any incentive anymore to favor decentralizing policies to centralizing ones, as long as it is in the interest of their constituency. ${ }^{15}$ Senators then become the protectors of regionally-based interests rather than state (or provincial) jurisdiction. ${ }^{16}$

The new situation in the Canadian Senate is different. At the present time, it is composed of 54 independent and 6 non-affiliated senators out of 101 sitting senators. ${ }^{17}$ As the Senate becomes more independent, legitimate, and assertive, it will almost inevitably become a new locus of political contention over provincial jurisdiction. One could say that it is a matter of political physics; legitimacy brings political power which, in turn, attracts groups that want to have their interests represented. This is especially true for 
interests groups whose voices cannot be channeled elsewhere because of the specific design of the political institutions or because of broader political dynamics. One can hardly argue that Québec has been an underrepresented player in Canadian federal institutions. However, the very design and history of the Senate and the new political tides in La Belle Province all converge in shedding new light on the potentially critical role of the upper chamber of Parliament in voicing Québec's grievances on federalism matters.

\section{Targeting the Senate as the Protector of Canadian Federalism}

Perhaps unsurprisingly, Québec seized the opportunity offered by a reinvigorated upper house to channel its specific political demands. In merely two years, from October 2016 when Prime Minister Justin Trudeau appointed the first cohort of independent senators - to November 2018, the status of the Senate in Québec politics has noticeably changed. Politicians of all stripes have repeatedly asked the Senate to stand up to protect the Canadian federal division of powers and to stop the Liberal Government when its ambitions are seen as encroaching on Provincial prerogatives. There have been three main events that have led to a senatorial call to arms by Québec.

The first was the introduction of Bill C-29 by the Trudeau Government on October 25, 2016. The bill was meant to reform the regulation of banks with some provisions respecting consumer protections. The timing was especially illchosen for such a reform. In 2014, the Supreme Court of Canada had just recognized that the application of Québec's Consumer Protection Act, a "characteristic of Québec's identity" according to University of Ottawa and former Québec Minister of Justice Benoît Pelletier, ${ }^{18}$ to banks does not impair the federal legislative jurisdiction over bank lending. ${ }^{19}$ The adoption of Bill C-29 would have jeopardized the application of the Québec Consumer Protection Act to banks, a hard-fought win for Québecers that they were visibly unwilling to let go.
In the face of this turn of events, the National Assembly unanimously adopted a resolution on November 29, 2016 requiring that the federal government "withdraws the provisions of its Bill C-29 [...] that would render inapplicable the provisions of the Consumer Protection Act regulating the relation between banks and their clients." ${ }^{20}$ When the Bill finally passed the House of Commons despite Québec's explicit demands, the Premier voiced his opinion outside the National Assembly and interjected his case directly to the Senate. ${ }^{21} \mathrm{He}$ asked "the Canadian Senate to play its role, the role of defender of Canada's regions and to stand up, and to say that it is out of the question to endorse such encroachment and amputation of Québec's jurisdiction."22 His voice was apparently heard because the Government, after the Senate expressed some concerns regarding this part of the bill, decided to withdraw the article that would have endangered the application of the Québec Consumer Protection Act.

The same scenario occurred in June 2017 when the federal budget bill, in addition to creating the Canada Infrastructure Bank, would have enabled the Government to designate it as a Crown agent for the purpose of specific infrastructure projects. Like other Crown corporations, the Bank could have been exempted from the application of provincial laws and municipal regulations. Québec's National Assembly again appealed to the Senate to block this part of the 2017-2018 Budget Bill. On May 31, 2017, the National Assembly adopted a unanimous resolution that "requires that Bill C-44, currently in the House of Commons, be amended to ensure that the Canada Infrastructure Bank is bound by the laws of Québec."23 The motion was sent to "the Federal Government, the Federal MPs from Québec and the senators." ${ }^{24}$ Senator André Pratte specifically channeled this concern in the Senate ${ }^{25}$ and Patrick Taillon, professor of constitutional law at Laval University, testified in the Standing Senate Committee on Banking, Trade, and Commerce to warn senators about the possible power imbalance that this bill would create between the federal government and the provinces. Pratte introduced a motion to sever the Infrastructure Bank from the remainder of the Budget Bill, but his motion was defeated and, 
despite efforts to amend it, the bill was adopted in the Senate without amendment.

The most important standoff between the House of Commons and the Senate since the reform of its appointment process was probably over the legalization of cannabis. The House of Commons passed Bill C- 45 to legalize cannabis in November 2017. By doing so, they fulfilled one of the main promises of the Liberal Party of Canada during the 2015 electoral campaign. When the bill arrived in the Senate, many senators were concerned, among other things, that the bill seemed clearly in contradiction with the expressed will of Quebec, Manitoba, and Nunavut to limit the rights of individuals to grow their own cannabis for personal use. Québec had already tabled its own bill regarding the regulation of cannabis in the province on November 16, 2017 after a special Summer-long consultation of the Committee on Health and Social Services. Jean-Marc Fournier, then-Minister of Intergovernmental Relations, went to the Senate on April 25, 2018 and argued that allowing individuals to grow as much as four plants was not part of the federal criminal law jurisdiction. As the debates continued in the Senate, the National Assembly echoed Fournier's remarks and adopted a unanimous resolution on May 9, 2018 to ask "that the Federal Government recognizes and respects the autonomy of Québec regarding the regulation of cannabis on its territory." ${ }^{26}$ The Assembly made sure to send the resolution specifically to all senators even though this would cause "mailing delays." 27 The Senate finally suggested 46 amendments, one of which would have given the provinces some latitude in deciding how many plants individuals could grow at home. The House of Commons refused to bend before this demand and returned the bill to the Senate in its original form. The Senate finally decided to yield to the will of the Commons just before the summer recess, but many senators made sure to express their discontentment with the Government's intransigence and warned about its possible political consequences. ${ }^{28}$

These three events are the external manifestation of the rise of the Senate as a genuine federal political player. But it also has internal manifestations in the Québec provincial politi- cal landscape. For example, in June 2017, the Couillard Government released its new constitutional policy document: Québecers, our way of being Canadian. ${ }^{29}$ The policy was meant to be a comprehensive overview and roadmap of the approach of the Couillard Government to federalism, intergovernmental relations, and the place of Québec in Canada. Among its many subjects, the policy criticized Trudeau's unilateralism in Senate appointments and asked that the Prime Minister consult with Québec before appointing senators. The document refers positively to the practice of Brian Mulroney between 1987 and $1990,{ }^{30}$ but fails to mention that this practice was a temporary provision of the Meech Lake Accord. ${ }^{31}$ The ratification of the Accord would have entrenched it in the Constitution, ${ }^{32}$ but its fate apparently doomed the practice ever since. Perhaps for the first time since the Charlottetown Accord, the role of Québec in the appointment of senators has returned to the fore in Québec provincial politics. ${ }^{33}$

For example, in light of Trudeau's first string of Senate appointments, the Coalition Avenir Québec (CAQ), Québec's then second opposition group and now governing party, introduced a bill in March 2016 to create a provincial mechanism to select Québec senators. The bill would have put in place a selection committee and a whole set of procedures through which Québec could have selected its own senatorial candidates. Those selected through this mechanism would have then been submitted to the Prime Minister for appointment to the Senate. ${ }^{34}$ The bill was defeated in the end, but its ideas are hardly far-fetched or out-of-touch with the political mainstream in Québec.

Now in power since the provincial election of October 1, 2018, it remains to be seen how much the Coalition Avenir Québec is willing to push its "new nationalism" with regard to the Senate. The official policy of the party, adopted in 2016, urges "comprehensive Senate reform" but it is not clear what this really means for the newly elected government. Will a new version of their bill suffice? In any event, the election of a more resolutely nationalist Government in Québec that does not threaten to separate from the rest 
of Canada and that seems willing to play within the institutions of Canadian federalism - is only likely to increase the pressure on the Senate coming from Québec in the upcoming years.

\section{Political Fragmentation in Québec and Canadian Federalism}

The rise of the Senate as a real political actor in charge of safeguarding the federal division of powers happens in conjunction with another development of Canadian constitutional politics that might amplify the impact of its resurgence. Since the 1980 referendum, in every federal election, Québecers have voted massively for one single party: it was the Progressive-Conservatives in 1984 and 1988, the Bloc Québécois in 1993, 1997, 2000, 2004, 2006, and 2008 and the NDP in 2011. Except for the Conservatives in 1984 and 1988, whose popularity in Québec was without a doubt due, in large part, to Mulroney's genuine willingness to bring Québec back into the Canadian federation, Québecers have, en masse, elected opposition parties to the House of Commons. ${ }^{35}$

This political situation made it possible for Québec's political elites to channel their concerns through Québec's federal representatives in the House of Commons of the Bloc Québécois or the NDP. The Bloc Québécois repeatedly asserted that its goal was to channel the consensus of the National Assembly in the House of Commons because "all decisions regarding the Québec Nation can only come from and be a decision of the Québec State as expressed through its National Assembly." ${ }^{36}$ It would thus be a mistake to think that the Bloc has always sided with separatists on all issues. From 2003 to 2011, the Bloc had the largest share of the Québec deputation in the House of Commons while, at the Provincial level, the federalist Liberals were in power. This did not prevent the Bloc from channeling the agreement of Québec's provincial MPs of all stripes, as expressed in unanimous resolutions adopted in the National Assembly on such issues as the opposition to the abolition of the long-gun registry, ${ }^{37}$ the employment insurance reform, ${ }^{38}$ the abolition of the mandatory long-form cen- sus, ${ }^{39}$ or the creation of the Canadian Securities Regulator. ${ }^{40}$ Likewise, during the 2011-2015 period, the NDP channeled the National Assembly's unanimous resolutions on several key issues, including mandatory bilingualism for Supreme Court judges, ${ }^{41}$ the protection of the funding of Radio-Canada, ${ }^{42}$ the opening of the federal government's confidential documents regarding the patriation of the Constitution ${ }^{43}$ and the application of Bill 101 to businesses falling under federal jurisdiction ${ }^{44}$ to name a few. ${ }^{45}$

However, the 2015 federal election changed the situation. For the first time, at least since 1980, Québecers have elected a diverse group of MPs and a very bare majority of Liberals to the House of Commons. As Louis Massicotte, professor of political science at Laval University, puts it, "it is as if Québecers, after having turned their back to Canadian governance ever since 1993, after the failure of the Meech Lake Accord, had decided to turn the page and to reinstate mainstream Canadian federal politics." 46 With the disaggregation of the political representation coming from Québec in the 2015 federal election and the steady decline of political cleavages along constitutional lines in Québec politics, Québec MPs in the House of Commons might lose their status as the prime defenders of Québec's distinct political interests and identity in Ottawa. Thus, it is perhaps unsurprising that the Senate has emerged and filled this gap.

It is also worth noting that the electoral reform would have likely accelerated this phenomenon. ${ }^{47}$ Canada's current first-past-the-post system gives a legislative premium to electoral pluralities. ${ }^{48}$ A more proportional electoral system would, ceteris paribus, greatly diminish the capacity of Québecers to send a large and homogenous cohort of MPs to the House of Commons that could channel their specific political grievances. Regardless of the eventual reform of the electoral system, the fact that Québec's demographic weight in Canada has steadily declined in the last forty years - and will continue to do so according to projections ${ }^{49}$ - is likely to put extra pressure on the Senate, at the expense of the House of Commons, as a primary channel for Québec's political grievances. 


\section{Conclusion}

The new appointment procedure to the Senate may very well become one of Trudeau's most important legacy. Informal institutional changes can be the most consequential ones for the political safeguards of Canadian federalism. Will the "new" Senate become the favourite locus of contention of provinces over matters of federalism? Yes and no. On the one hand, it might become so for Québec because of its internal political dynamics and its important numerical representation in the Upper House. In all likelihood, Québec's political elites will increasingly see senators as their allies in their fights against centralizing tendencies of the federal government.

On the other hand, this renewed dynamism is not likely to decrease the reliance on the courts as the main watchdogs of Canadian federalism elsewhere in Canada. Alberta, for one, does not have the same kind of leverage in the Senate that Québec has. Nevertheless, cheap and rapid senatorial victories, even though they might be more fragile than hard-fought judicial ones, might for some time placate those who recently saw "Triple-E" reforms or outright abolition as the only two alternatives for the future of the Upper House of Parliament. Will the Supreme Court itself take notice of the reinvigorated Senate and use it to justify a more deferential approach towards the federal division of powers as its counterpart in the United States has done? Only time will tell. If the quarrel between Ottawa and Québec over cannabis spills over into the judicial arena, as both have promised it would if they had to defend the validity of their respective laws, we might know sooner rather than later.

\section{Endnotes}

* Jean-Christophe Bédard-Rubin, S.J.D. Candidate, University of Toronto.

1 The idea is articulated at different places in the Federalist papers.

2 Garcia $v$ San Antonio Transit Authority, 469 US 528 at 552 (1985).

3 Perhaps the most famous articulation of this idea is Herbert Wechsler, "The Political Safeguards of Federalism: The Role of the States in the Composition and the Selection of the National Government" (1954) 54 Colum L Rev 543 [Herbert]. Since the revival of judicial limitation of Congressional authority on federalism grounds in 1995, also known as the "federalism revolution", the idea of the political safeguards of federalism has apparently lost much of its appeal for the majority of the United States Supreme Court. See United States v Lopez, 514 US 549 (1995). See also Erwin Chemerinsky, Constitutional Law: Policies and Principles, 5th ed (New York: Wolters Kluwer, 2015) at 272-81, 326-40.

4 See Herbert, ibid.

5 See Sanford Levinson, Framed: America's 51 Constitutions and the Crisis of Governance (Oxford: Oxford University Press, 2012) at 134.

6 These are the United States Census Bureau estimates for 2016. US, Census Bureau, Population Estimates, Population Change, and Components of Change, (18 January 2017), online: <www2.census. gov/programs-surveys/popest/tables/2010-2016/ state/totals/>.

7 For a good summary of the history of the Senate, its role in Canadian constitutional culture and architecture and its various failed reforms, see David Schneiderman, Red, White and Kind of Blue?: The Conservatives and the Americanization of Canadian Constitutional Culture (Toronto: University of Toronto Press, 2015) at Ch 4.

8 Wade K Wright, "The Political Safeguards of Canadian Federalism: The Intergovernmental Safeguards" (2016) 36 NJCL 1 at 17 [Wade].

9 Reference re Supreme Court Act, ss 5 and 6, [2014] 1 SCR 433, 2014 SCC 21.

10 See e.g. Sean Kilpatrick, "Canada's Senate Scandal, A Timeline - from Clashes over Primary Residence to Duffy's Documents", National Post (29 October 2013), online: <http://nationalpost. $\mathrm{com} /$ news/politics/canadas-senate-scandal-atimeline-from-clashes-over-primary-residencesto-duffys-documents $>$.

11 For a first-hand account of the Liberal strategy, see Stéphane Dion, “Time for Boldness on Senate Reform, Time for the Trudeau Plan” (2015) 24 Const Forum Const 61.

12 Prime Minister of Canada, News Release, "Prime Minister Announces Intention to Recommend the Appointment of Nine New Senators" (27 October 2016), online: <https://pm.gc.ca/eng/ news/2016/10/27/prime-minister-announcesintention-recommend-appointment-nine-newsenators $>$. 
13 Elaine McCoy, "Why a More Independent Senate is Working Better for Canadians", Maclean's (21 August 2017), online: <www.macleans.ca/opinion/ why-a-more-independent-senate-is-workingbetter-for-canadians/>.

14 Akhil Reed Amar, America's Constitution: A Biography, (New York: Random House, 2006) at 411.

15 See Sanford Levinson, Framed: America's 51 Constitutions and the Crisis of Governance (New York: Oxford University Press, 2009) at 147-48.

16 Wade, supra note 8 at 18.

17 As of December 2018, there are 4 vacant seats.

18 Jean-Marc Salvet, "Couillard appelle le Sénat à renverser une décision de Trudeau ", Le Soleil (7 December 2016), online: <www.lesoleil.com/ actualite/politique/couillard-appelle-le-senat-arenverser-une-decision-de-trudeau-9ca572148c9 5079168e3ad449f455b02>.

19 Bank of Montreal v Marcotte, 2014 SCC 55, [2014] 2 SCR 725.

20 This is my translation. Québec, National Assembly, Votes and Proceedings, 41st Leg, 1st Sess, No 214 (29 November 2016), online: <www.sqrc.gouv.qc.ca/ relations-canadiennes/positions-historiques/ motions/2016-11-29-protection-consommateur. pdf $>$.

21 Tommy Chouinard, " Couillard appelle à l'aide le Sénat contre une loi de Trudeau ", La Presse (7 December 2016), online: <www. lapresse.ca/actualites/politique/politiqueQuébecQuébecoise/201612/07/01-5048958couillard-appelle-a-laide-le-senat-contre-une-loide-trudeau.php $>$.

22 The original version in French reads: "Nous interpellons le Sénat canadien à jouer son rôle, à jouer son rôle de représentant des régions du Canada, et de se lever, et de dire qu'il n'est pas question d'entériner une encoche ou une amputation des responsabilités du Québec. » Ibid.

23 This is my translation. The text of the resolution, in French, reads : "Que l'Assemblée nationale affirme l'application de toutes les lois du Québec aux éventuels projets soutenus par la Banque d'infrastructure du Canada et que pour refléter clairement cet état de droit, quelle exige des amendements au projet de loi C-44 présentement étudié à la Chambre des communes, afin de démontrer que la Banque d'infrastructure du Canada est soumise aux lois du Québec. » Québec, National Assembly, Votes and Proceedings, 41st Leg, 1st Sess, No 261 (31 May 2017), online: <www.assnat.qc.ca/fr/travaux-parlementaires/ assemblee-nationale/41-1/journal-debats/ 20170531/199043.html>.
24 Ibid.

25 On the third reading of the Bill, he said: "As far as protecting provincial jurisdictions is concerned, despite the government's assurances, I believe that the bill could have been amended to ensure that the agent of the Crown status conferred on the bank does not exempt projects funded by the bank from the jurisdiction of applicable provincial laws. Since the government felt that there was no risk of that, I fail to see why it couldn't simply indicate that clearly in the legislation.” Nevertheless, Pratte ended up voting in favour of the bill. Canada, Senate of Canada, Hansard, 42nd Parl, 1st Sess, No 136 (21 June 2017), online: <https://sencanada.ca/en/ content/sen/chamber/421/debates/136db_201706-21-e?language $=e>$.

26 Québec, National Assembly, Votes and Proceedings, 41st Leg, 1st Sess, No 337 (9 May 2018), online: $<$ www.assnat.qc.ca/fr/travaux-parlementaires/ assemblee-nationale/41-1/journal-debats/ 20180509/220465.html>.

27 Ibid.

28 Canada, Senate of Canada, Hansards, 42nd Parl, 1st Sess, No 223 (19 June 2018), online: <www. sencanada.ca/Content/SEN/Chamber/421/ Debates/pdf/223db_2018-06-19-e.pdf $>$.

29 Québec, Gouvernement du Québec, Québec Québecers, Our Way of Being Canadian: Policy on Québec Affirmation and Canadian Relations, (Québec: Gouvernement du Québec, 2017), online: $<$ www.saic.gouv.qc.ca/documents/relationscanadiennes/politique-affirmation-en.pdf $>$.

30 This practice stemmed from the Meech Lake Accord that provided that until the adoption of the Accord, the Prime Minister would only appoint senators that had previously been submitted by the Québec Government. Québec, Gouvernement du Québec, Québécois, notre façon d'être canadiens: Politique d'affirmation du Québec et de relations canadiennes, (Québec: Gouvernement du Québec, 2017) at 36-37.

31 Meeting of the First Ministers on the Constitution, 1987 Constitutional Accord, (Ottawa: 3 June 1987) art 4, online: <www.sqrc.gouv.qc.ca/documents/ positions-historiques/positions-du-qc/part3/ Document22_en.pdf $>$.

32 Canada, House of Commons, Constitution Amendment, 1987, being the Schedule of a Motion for a Resolution to Authorize an Amendment to the Constitution of Canada made pursuant to the 1987 Constitutional Accord in Debates, Vol VIII, 33rd Parl, 2nd Sess, at 10408-10 (26 October 1987) art 2, online: <www.sqrc.gouv.qc.ca/documents/ 
positions-historiques/positions-du-qc/part3/ Document22_en.pdf $>$.

33 As a side note, I think it is fair to say that the internal problems of the Senate, especially the Duffy-Wallin-Brazeau affair, have received far less media coverage and public attention in Québec than in the rest of Canada.

34 Bill 592, Loi concernant la sélection des sénateurs représentant le Québec, 42nd Parl, 1st Sess, (defeated on 6 March 2016).

35 In the 2000 Federal election, the Bloc Québécois won a narrow majority (38) of the 75 MPs from Québec to the Liberals (36) despite losing the popular vote to the Liberals $39,9 \%$ to $44,2 \%$ in the province. However, unlike the 2015 election, the split was largely along linguistic lines and the two parties won all the seats in Québec but one.

36 Bloc Québécois, Statuts et Règlement du Bloc Québécois, (Ottawa: Bloc Québécois, 2017) at 4, online: <www.blocquebecois.org/wp-content/ uploads/2017/01/statuts-et-re_glements-2017. pdf $>$.

37 Québec, National Assembly, Votes and Proceedings, 39th Leg, 1st Sess, No 69 (4 November 2009), online: $<$ www.saic.gouv.qc.ca/relations-canadiennes/ positions-historiques/motions/2009-11-04resolution-registre-armes.pdf >; Québec, National Assembly, Votes and Proceedings, 37th Leg, 2nd Sess, No 47 (18 October 2006), online: <www. sqrc.gouv.qc.ca/relations-canadiennes/positionshistoriques/motions/2006-10-18-resolutionregistre-armes.pdf $>$; Québec, National Assembly, Votes and Proceedings, 39th Leg, 2nd Sess, No 55 (27 October 2011), online: <www.saic.gouv.qc.ca/ relations-canadiennes/positions-historiques/ motions/2011-10-27-registre-armes-feu.pdf>; See e.g. House of Commons, Hansard, 40th Parl, 2nd Sess, No 85 (28 September, 2009), online: <https:// openparliament.ca/debates/2009/9/28/sergemenard-2/>.

38 Québec, National Assembly, Votes and Proceedings, 40th Leg, 1st Sess, No 7 (13 November 2012), online: <www.saic.gouv.qc.ca/relations-canadiennes/ positions-historiques/motions/2012-11-13loi-assurance-emploi.pdf>. See e.g. House of Commons, Hansard, 41st Parl, 1st Sess, No 248 (7 May, 2013), online: <https://openparliament.ca/ debates/2013/5/7/jean-francois-fortin-1/>.

39 Québec, National Assembly, Votes and Proceedings, 39th Leg, 1st Sess, No 136 (28 September 2010), online: <www.sqrc.gouv.qc.ca/relationscanadiennes/positions-historiques/motions/201009-28-recensement.pdf $>$. See e.g. House of Commons, Hansard, 40th Parl, 3rd Sess, No 73 (29
September 2010), online: <https://openparliament. ca/debates/2010/9/29/robert-bouchard-1/>.

40 Québec, National Assembly, Votes and Proceedings, 39th Leg, 1st Session, No 127 (4 June 2010), online: <www.sqrc.gouv.qc.ca/relationscanadiennes/positions-historiques/motions/201006-04-valeur-immobiliere.pdf>; See e.g. House of Commons, Hansard, 40th Parl, 3rd Sess, No 60 (10 June 2010), online: <https://openparliament.ca/ debates/2010/6/10/guy-andre-3/>.

41 Québec, National Assembly, Votes and Proceedings, 38th Leg, 1st Sess, No 86 (21 May 2008), online: <www.sqrc.gouv.qc.ca/relations-canadiennes/ positions-historiques/motions/2008-05-21-juge. pdf>. See e.g. Bill C-208, An Act to amend the Supreme Court Act, 41st Parl, 2nd Sess, (defeated on 7 May 2014), online: <https://openparliament. ca/bills/41-2/C-208/>.

42 Québec, National Assembly, Votes and Proceedings, 41stLeg, 1stSess, No47 (26 November 2014), online: <www.sqrc.gouv.qc.ca/relations-canadiennes/ positions-historiques/motions/2014-11-26-radiocanada.pdf $>$; See e.g. House of Commons, Hansard, 41st Parl, 2nd Sess (26 November 2014), online: $<$ https://openparliament.ca/debates/2014/11/26/ pierre-nantel-1/>.

43 Québec, National Assembly, Votes and Proceedings, 40th Leg, 1st Sess, No 39 (16 April 2013), online: <www.sqrc.gouv.qc.ca/relations-canadiennes/ positions-historiques/motions/2013-04-16-loiconstitutionnelle.pdf>; See e.g. John Mahoney, "Megan Leslie: "The NDP's Federalist Mission", National Post (7 May 2013), online: <http:// nationalpost.com/opinion/ndp-counterpoint-bymegan-leslie> [Mahoney].

44 Bill C-315, An Act to amend Canada Labour Code (French Language), 41st Parl, 1st Sess, (defeated on 29 February 2012).

45 Megan Leslie, Deputy Leader of the Official Opposition and NDP MP from Halifax even went so far as to argue that it was the NDP's role to channel Québec's unanimous consent in Ottawa. See Mahoney, supra note 43. Despite punctual convergence between the NDP's political positions and Québec's National Assembly unanimous resolutions between 2011 and 2015, the relation of the NDP with Québec has been historically far from harmonious. See André Lamoureux, "Impasse historique, vague orange et nouvelle ère Mulcair: le Nouveau Parti Démocratique et l'épreuve du Québec » (2012) 21:1 Bull d'hist pol 207.

46 This is my translation of Louis Massicotte, " Le retour de l'enfant prodigue. Les Québécois et 
lélection fédérale canadienne de 2015 », (2015) 6 IdeAs 1 at 1.

47 Christian Dufour articulated this view in his brief submitted to the Electoral Reform Committee of the House of Commons. See House of Commons, Special Committee on Electoral Reform, 42nd Parl, 1st Sess, No 14 (22 August 2016), online: <www. ourcommons.ca/Content/Committee/421/ERRE/ Evidence/EV 8399842/ERREEV14-E.PDF>; He had already articulated his views earlier in Christian Dufour, "Proportionnelle: attention!", La Presse (4 March 2003), online: <https:// vigile.QuébecQuébec/archives/ds-democratie/ docs3/03-3-4-dufour-reforme.html>.

48 Arend Lijphart, Patterns of Democracy: Government Forms and Performance in ThirtySix Countries, (New Haven: Yale University Press, 1999) at Ch 8.

49 Statistics Canada, Population Projections for Canada (2013 to 2063), Provinces and Territories (2013 to 2038), (Ottawa, Statistics Canada, 30 November 2015), online: <www.statcan.gc.ca/ pub/91-520-x/2014001/hi-fs-fra.htm>. 
